\title{
Prevalência de sintomas de asma, rinite e eczema atópico entre crianças e adolescentes brasileiros identificados pelo International Study of Asthma and Allergies (ISAAC) - Fase 3
}

\author{
DIRCEU SOLÉ1 ${ }^{1}$ GUSTAVO F. WANDALSEN², INÉS CRISTINA CAMELO-NUNES ${ }^{3}$, \\ CHARLES NASPITZ, ISAAC-GRUPO BRASILEIRO ${ }^{4}$
}

1. Professor titular, Universidade Federal de São Paulo - Escola Paulista de Medicina (UNIFESP-EPM), São Paulo. SP

2. Mestre, (UNIFESP-EPM), São Paulo, SP.

3. Doutora, Pesquisadora Associada, UNIFESP-EPM, São Paulo. SP.

4. ISAAC - Grupo Brasileiro: Maria Socorro Cardoso (Manaus, Amazonas); Bruno A. Paes Barreto (Belém, Pará); Vera Dantas (Natal, Rio Grande do Norte); Murilo Britto (Recife, Pernambuco); Almerinda R. Silva, Emanuel Sarinho (Caruaru, Pernambuco); Francisco J. Passos Soares, Mércia Lamenha Medeiros Santos (Maceió Alagoas); Jackeline Motta, Ricardo Gurgel (Aracaju, Sergipe); Leda Solano de Freitas (Feira de Santana, Salvador e Vitória da Conquista, Bahia); Wellington Borges (Brasília, Distrito Federal); Paulo Augusto Camargos (Belo Horizonte, Minas Gerais); Fábio Kuschnir, Antônio José Ledo Alves da Cunha (Nova Iguaçu, Rio de Janeiro); Antônio Carlos Pastorino (São Paulo - Oeste, São Paulo); Karyn Chacon de Mello (São Paulo - Sul, São Paulo); Cassia Gonzalez, Neusa F Wandalsen (Santo André São Paulo); Carlos Riedi, Nelson A. Rosário Filho (Curitiba, Paraná); Cláudia Benhardt (Itajaí Santa Catarina); Arnaldo Porto (Passo Fundo, Rio Grande do Sul); Gilberto B. Fischer (Porto Alegre, Rio Grande do Sul); Vitor E. Cassol (Santa Maria, Rio Grande do Sul).

\begin{abstract}
Prevalence of symptoms of asthma, rhinitis, and atopic eczema among Brazilian children and adolescents identified bye the Internacional Study of Asthma and allergies in Childhood (ISAAC)- Phase 3

Objetivo: Determine the prevalence of symptoms related asthma, rhinitis eczema and atopic in school (EC) between 6 and 7 years and adolescents (ad) between 13 and 14 years, residents in 20 Brazilian cities, using the written questionnaire standardized of Isaac, and assess their Association with the latitude, altitude and annual average temperature of centres of residence. Methods: Participated in the EC study and ad of the five regions of Brazil, 23. 422 Isaac questionnaires completed by the parents of Ech and 58.4.2 144(2) by own ad. The indices of latitude, altitude and annual average temperature were obtained from the Brazilian Institute of geography and statistics. Results: The prevalências medium-sized to the EC and ad, respectively, were: asthma Active, 24, 3 and 19,0\% rhinoconjunctivitis, 12, 6 and 14, 6\% and eczema flexural, 8, 2 and 5, 0\%. Association signifier negative was observed between latitude and prevalence of asthma diagnosed by doctor to the EC, asthma, serious asthma diagnosed by medical, eczema and eczema flexural to the ad. There was no Association with the altitude. Conclusion: The prevalence of asthma,
\end{abstract}


rhinitis eczema and atopic in Brazil was variable. Higher values, particularly of asthma and eczema, were observed in centers located closer to Ecuador.

(Key words: Crianças, asma, eczema atópico, rinite, rinoconjuntivite alérgica, prevalência, ISAAC, epidemiologia).

J. Pediatr (Río J). 2006; 82 (5): 341-6

ESTE TRABAJO LO PUEDE ENCONTRAR EN EXTENSO EN WWW.SCIELO.CL 